\title{
The Broad Range of Coronaviruses Co-existing in Chiropteran: Implications for One Health
}

\author{
D. Katterine Bonilla-Aldana ${ }^{1,2}$, Catalina Toro-Ortiz ${ }^{3}$, Paula Jimenez-Salazar ${ }^{3}$, Valeria Guevara-Manso ${ }^{3}$, S. Daniela Jimenez- \\ Diaz $^{1}$, Jorge L. Bonilla-Aldana ${ }^{4}$, Erwin J. Gutierrez-Grajales ${ }^{2}$, Samuel Pecho-Silva ${ }^{5,6}$, Alberto Paniz-Mondolfi ${ }^{7,8,9}$, Jose \\ Antonio Suárez ${ }^{10}$, Monica R. Pachar ${ }^{11}$, Dayron F. Martinez-Pulgarin ${ }^{2}$, Lysien I. Zambrano ${ }^{12}$, Diego Soler-Tovar ${ }^{13}$, Alfonso J. \\ Rodriguez-Morales ${ }^{2,6,14}$, and Salim Mattar ${ }^{15}$ \\ ${ }^{I}$ Semillero de Investigación en Zoonosis (SIZOO), Grupo de Investigación BIOECOS, Fundación Universitaria Autónoma de las Américas, Sede Pereira, Pereira, \\ Risaralda, Colombia \\ ${ }^{2}$ Latin American Network of COVID-19 Research (LANCOVID), Pereira, Colombia \\ ${ }^{3}$ Faculty of Veterinary Medicine and Zootechnics, Fundación Universitaria Autónoma de las Américas, Sede Pereira, Pereira, Risaralda, Colombia \\ ${ }^{4}$ School of Veterinary Medicine and Zootechnics, Universidad de la Amazonia, Florencia, Caqueta, Colombia \\ ${ }^{5}$ Hospital Nacional Edgardo Rebagliati Martins, Lima, Peru \\ ${ }^{6}$ Master in Clinical Epidemiology and Biostatistics, Universidad Cientifica del Sur, Lima, Peru \\ ${ }^{7}$ Laboratory of Medical Microbiology, Department of Pathology, Molecular and Cell-based Medicine, The Mount Sinai Hospital-Icahn School of Medicine at Mount Sinai, \\ New York, USA \\ ${ }^{8}$ Laboratorio de Señalización Celular y Bioquímica de Parásitos, Instituto de Estudios Avanzados (IDEA), Caracas, Caracas, Venezuela \\ ${ }^{9}$ Academia Nacional de Medicina, Caracas, Venezuela. \\ ${ }^{10}$ Investigador SNI Senacyt Panamá, Clinical Research Deparment, Instituto Conmemorativo Gorgas de Estudios de la Salud, Panamá City, Panama \\ ${ }^{11}$ Medicine Department-Infectious Diseases Service, Hospital Santo Tomas, Panama City, Panama \\ ${ }^{12}$ Scientific Research Unit, School of Medical Sciences, Universidad Nacional Autónoma de Honduras (UNAH), Tegucigalpa, Honduras \\ ${ }^{13}$ Epidemiology and Public Health Group, School of Agricultural Sciences, Universidad de La Salle, Carrera 7 No. 179-03, Bogotá, Colombia \\ ${ }^{14}$ Grupo de Investigación Biomedicina, Faculty of Medicine, Fundación Universitaria Autónoma de las Américas, Pereira, Risaralda, Colombia \\ ${ }^{15}$ Instituto de Investigaciones Biologicas del Tropico, Universidad de Cordoba, Monteria, Colombia \\ *Corresponding Author’s Email: arodriguezmo@ cientifica.edu.pe, (DORCiD: 0000-0001-9773-2192
}

\begin{abstract}
Bats are a group of mammals that harbor the most significant number of coronaviruses. The aim of present review article was to analyze the broad spectrum of the coronavirus coexisting in Chiropterans hosts. Bats have certain types of cell receptors that allow them to be the potential hosts of a large number of viruses without the presence of any clinical manifestations, and to be a source of contagion infections for other animals and human species. Emphasis can be placed on five coronaviruses, such as Porcine Epidemic Diarrhea Disease, Severe Acute Diarrhea Syndrome, Middle East Respiratory Syndrome, Severe Acute Respiratory Syndrome, and Severe Acute Respiratory Syndrome 2, which have had significant impacts causing epidemic outbreaks in different parts of the world, and generating implications for both human and animal health. In conclusion, recent research indicated the importance of bats as potential hosts of multiple coroaviruses leading to some zoonotic diseases.
\end{abstract}

Keywords: Bats, Coronaviruses, Cross-species, Evolution, Spillover, Transmission

\section{INTRODUCTION}

Bats are a group of mammals that harbor the most significant number of coronaviruses. Coronaviruses are an extensive family of enveloped RNA viruses, having the ability to infect many species of animals and human beings (BonillaAldana et al., 2020a; Bonilla-Aldana et al., 2020b; Bonilla-Aldana et al., 2021). The types of coronaviruses with high pathogenicity include Severe Acute Respiratory Syndrome Coronavirus (SARS-CoV), Middle East Respiratory Syndrome (MERS-CoV), and the most recent one named SARS-CoV-2 (Bonilla-Aldana et al., 2020a; Bonilla-Aldana et al., 2020b; Bonilla-Aldana et al., 2020f). One of the existing hypotheses given by the co-evolutionary history of bats and virus classes is a bat-virus relationship, which allows both to exist in constant equilibrium, managing to survive together (Banerjee et al., 2018; Wong et al., 2019; Basu-Ray et al., 2020). Bats have diversified cell types and receptors. Therefore, the bats can be potential hosts of many viruses, and thus the spread of viruses increases the possibility of transmission (Bonilla-Aldana et al., 2020c; Bonilla-Aldana et al., 2020d).

Interactions among bats with other animal species and humans can be critical factors for the transmission of coronaviruses, leading to devastating pandemics that affect the whole world (Bonilla-Aldana et al., 2020e; Dhama et al., 2020a; Dhama et al., 2020b). A great example of bat-human interactions occurred in China and Vietnam's restaurants and wildlife markets where zoonotic transmission of viruses has occurred (Wong et al., 2019; Huong et al., 2020). 


\section{BIOLOGY OF BATS}

\section{Taxonomy}

Bats are among the most diverse mammal order, second after rodents, with a complex taxonomy that is still under study because of conflicting phylogenetic relationships in light of new genetic data, especially at lower taxonomy levels (Amador et al., 2018). These mammals from the order Chiroptera with more than 1400 species share the evolutive characteristic of forelimbs adapted as wings. They were traditionally divided into macro and micro Chiroptera, assuming an independent evolution. However, recent DNA sequence data suggested that megabats (Macrochiropetara) originated during the early Eocene, and shared genetic material with microbats (Tsagkogeorga et al., 2013; Solari et al., 2019). The new proposed suborder is Yinpterochiroptera, including Pteropodidae (megabats) and Rhinolophoidae (horseshoe bats and megadermatidae or false vampire bats). The other suborder is Yangochiroptera (also known as Vespertilioniformes), and is composed of most of the microbat families; echolocation and eating habits evolution are one of the characteristics used in this new classification (Teeling et al., 2000; Eick et al., 2005).

The oldest fossil record of the modern bat ancestor is Onychonycteris finneyi, which dated back to the early Eocene (approximately 52.5 million years ago, as a part of the Tertiary Period Cenozoic Era) from the Green River Formation of Wyoming, USA. This fossil proves a piece of evidence that bats evolved the ability to fly before echolocation (Simmons et al., 2008). Currently, the order Chiroptera is composed of more than 1400 species, and various species can evolve together with different viruses. Members of both suborders act as reservoirs or susceptible hosts for several zoonotic viruses that are highly pathogenic in humans (Calisher et al., 2006; Moratelli and Calisher, 2015a; Banerjee et al., 2018). Without causing clinical disease in natural or experimental bats, these flying mammals vary widely in size, shape, and mass, with species weighting from two grams (Craseonycteris thonglongyai) to even one kilogram (Acerodon jubatus). They are distributed in the world on all continents except Antarctica (Banerjee et al., 2018; Wong et al., 2019).

Their biological diversity is as complex as their taxonomy and their feeding habits range from frugivorous (megabats) to insectivorous, carnivorous, and hematophagous in the Yangochiroptera suborder (Solari and Baker, 2007; Banerjee et al., 2018). They are nocturnal mammals, with one or two peaks of activity during the night; they inhabit a variety of ecological sites, including trees, caves, and other human-made structures, such as tunnels, deserted and occupied houses in rural areas. They spend their time in roosts, creating huge colonies like the one in Bracken cave in the United States of America (Moratelli and Calisher, 2015b), which is composed of more than 20 million bats (Tadarida brasiliensis mexicana) (Han et al., 2015).

Although sometimes they are considered seasonal animals. Some species have migratory behavior, especially in temperate zones. They are short-distance migrators, which raises concern about the probability of transmission of pathogens by this species (Pipistrellus spp, Tadarida brasiliensis, Vespertilio, and Nyctalus spp.). When they are active, bats provide critical services for the ecosystem by regulating crop pests, as pollinators and dispersing seeds (they are vital for the live cycle of Baobab African tree, Adansonia digitata), and fertilizing the soil with their excreta, which is rich in nitrogen control of vectors such as mosquitoes. Bats are used in applied immunogenetic research, as healthy aging models. They have been impacted by the White Nose Syndrome (Pseudogymnoascus destructans). It has been suggested that there has been a decline in the bat population caused by this fungal infection. There are millions of pounds of insects that are not eaten and has turned into a burden for agriculture (Kasso and Balakrishnan, 2013).

Besides their intricate relationship with the environment, with repercussions on human well-being, several host pathogens cause disease in humans. Bats can store around 23 families of detected viruses; some are biological agents responsible for the zoonosis in which the coronavirus is found (Banerjee et al., 2018; Wong et al., 2019).

Knowledge about the bat coronaviruses (Bat-CoV) has increased over the past decade. It is estimated that not lees than 3,204 Bat-CoV worldwide exists. It is known now that they are the main ecological drivers of the diversity of coronaviruses and their evolutionary reservoirs (Banerjee et al., 2019). Bats possess adequate traits to host more viruses, whether these are zoonotic, providing them with a long lifespan for their body size and generating the viral persistence of chronic infections (Lacroix et al., 2017; Banerjee et al., 2019; Wong et al., 2019). The decrease in the physiological activity of the animal in a long way can reduce the immune function and viral replication (Lacroix et al., 2017; Banerjee et al., 2019; Wong et al., 2019).

Due to their role as a primary source of emerging infectious diseases worldwide, the study of the zoonosis associated with bats is vital for understanding the dynamics of transmission, prevention, and control of these pathogens (Banerjee et al., 2018). The bats' ability to be the host of hundreds of viruses without manifesting disease is an extensive area of research, and one of the peculiarities is that these mammals act as a source of infectious diseases. As bats are distributed worldwide with a wide diversity of species at multiple habitats, there is a matter of concern and a field for future related research. They are the only mammals that can fly, look for food daily, and migrate seasonally. For example, the Nathusius's bat (Pipistrellus nathusii) showed a mean speed of $47 \mathrm{~km} / \mathrm{day}$ (Hedenström, 2009). Some species can fly over the ocean up to $14 \mathrm{~km}$ from the shore (Ahlén et al., 2009). They can facilitate their flight by having hollow bones to reduce body mass (Han et al., 2015; Fleming, 2019). 


\section{Immunology of coronavirus in bats}

Bats possess properties that modify their immune function and allow them to be reservoirs and vectors of diseases instead of being clinically infected (Calisher et al., 2006; Allen et al., 2009). It has been observed during the coevolutionary history of bats and viruses that they have formed a unique host-pathogen relationship. Coronaviruses cause little or no harm to bats and can take months or years to manifest the disease (Schountz, 2014; Banerjee et al., 2018).

One of the existing hypotheses indicates that bats are not infected by the viruses due to the high body temperature during their flight. They mimic the effects of the response to fever, which results from the consumption of ATP which increases mitochondrial activities facilitating host responses. However, by itself, it is not enough to explain how bats can host viruses without signs of disease. Bats' cells are suggested to interfere with viral replication with the constitutive Interferon (IFN) activity, as well as, with active INF-stimulated Genes (ISG). It has also been suggested that bats use Pattern Recognition Receptors (PRRs) as a surveillance system for infectious threats (Schountz, 2014; Flies and Woods, 2019).

The first lines of evidence that associate a pathogen with a host are detecting combined genome fragments that may have circular DNA or linear RNA from one or two fragmented lines, A cell suitable for spreading a virus must be permissive and also be able to carry proper receptors that allow it to bind to an incoming virus. The immunological characteristics presented above are unique in bats, and allow them to be a virus carrier without getting sick (Dobson, 2005; Han et al., 2015). Some types of bats hibernate so their body temperature and metabolic rate are lowered, and immune responses are suppressed to conserve energy during the winter (George et al., 2011). It is believed that one possible mechanism of transmission of viruses from bats is through their saliva and urine, which can contaminate both the soil and fruits. So the contaminated fruits/soil can be ingested by intermediate hosts, including horses, pigs, civets, or non-human primates (Han et al., 2015). The pathogenicity of such viruses for human beings is still unknown, and possible threats need to be determined. Viruses transmitted by bats have been found in different species and geographical distribution, which indicates that they have been expanding the disease (Han et al., 2015). The related example is pandemic coronaviruses for which bats have been identified as a reservoir par excellence since they are ideal for hosting and transporting the virus to intermediate hosts through wet markets or illegal trafficking resulting in endangering human health (Huong et al., 2020).

\section{Coronavirus}

Bats have been the natural reservoir of the coronaviruses for many years (Table 1). Bats have been evolved over the years by immune and biological changes. These animals are sociable and live in colonies of at least 500 bats per square foot, facilitating the transmission of viruses from bat to bat (Han et al., 2015; Mackenzie et al., 2016).

Coronaviruses $(\mathrm{CoV})$ are part of an extensive family of Coronaviridae, subfamily Coronavirinae and order Nidovirales. They present an envelope, and are made up of the most extended single-stranded RNA chains present in unsegmented positive sense vertebrates, and have the particularity of producing new strains and recombining; this virus has a high capacity to adapt to its host, and has been classified into four different genuses; Alphacoronavirus, Betacoronavirus, Gammacoronavirus, and Deltacoronavirus (Table 1) (Wong et al., 2019; Dos Santos Bezerra et al., 2020). Coronaviruses contain the protein S located on the surface; it will enable the start of infection by recognizing receptors and membrane fusion; it is a critical factor in the host's specificity (Banerjee et al., 2018).

This virus is highly contagious and zoonotic, which indicates that the transmission can occur from a vertebrate animal to a human, and presents great importance to global public health, being associated with multiple outbreaks that remain an unknown phenomenon. Coronaviruses circulate in nature in various animal species. Alpha-coronaviruses (alphaCoV) and beta-coronaviruses (betaCoV) can infect mammals, while gamma-coronaviruses and delta-coronaviruses mainly infect birds (Mollentze and Streicker, 2020; Rodriguez-Morales et al., 2020). These viruses have been detected globally, and alphaCoV and betaCoV have originated from bats in regions such as Asia, Africa, Europe, North and South America, as well as Australasia (Table 2).

The first case of coronavirus originated from bats and transmitted by an intermediate host was called palm civet, Paguma larvata, which was registered during 2002-2003 in the province of Guangdong in China. In the year 2012, the Middle East Respiratory Syndrome Coronavirus (MERS- CoV), which originated from bats, manifested itself in Saudi Arabia with dromedary camels (Camelus dromedarius) as an intermediate host. In December 2019, an unidentified pathogen emerged in Wuhan, China, causing severe pneumonia, and later in January 2020, a novel coronavirus (nCoV2019, currently SARS-CoV-2) was described as the cause. Since then, a global emergency has been aroused due to the pandemic caused by SARS-CoV-2 (the current taxonomic name of the new coronavirus). It is supposed that Coronavirus disease 2019 (COVID19) is originated from bats, but the intermediate host is still undefined. Some coronavirus genuses, such as SARS-CoV and several betaCoVs of the subgenus Merbecovirus, are known to be closely related to MERS-CoV and have a common reservoir as horseshoe bats (Wong et al., 2019) (Table 2). 
Table 1. Reported Coronaviruses described in bats and other hosts

\begin{tabular}{|c|c|c|c|}
\hline Coronavirus & Main affected hosts & Intermediate hosts & Natural hosts \\
\hline Porcine epidemic diarrhea virus & Pigs & Unknown & Bat (Scotophilus kuhlii) \\
\hline Swine acute diarrhea syndrome coronavirus & Pigs & Uknown & Bat (Rhinolophus spp.) \\
\hline Middle East respiratory syndrome coronavirus & Human and other animals & Camels (Camelus dromedarius) & Bats (Taphozous) \\
\hline Severe acute respiratory syndrome coronavirus & Human and other animals & Civets and Himalayan pangolin & Bats (Rhinolophidae) \\
\hline Severe acute respiratory syndrome coronavirus 2 & Human and other animals & Still unknown, suspected: pangolin & Bats? \\
\hline
\end{tabular}

? Bats are still questioned and studied for SARS-CoV-2.

Human and other animals

Table 2. Comparison of epidemic coronavirus versus other dangerous zoonotic bat viruses

\begin{tabular}{|c|c|c|c|c|c|}
\hline \multirow[b]{2}{*}{ Features } & \multicolumn{3}{|c|}{ CORONAVIRUS* } & \multirow{2}{*}{$\begin{array}{c}\text { FILOVIRUS } \\
\text { Marburg virus*** }\end{array}$} & \multirow{2}{*}{$\begin{array}{c}\text { PARAMYXOVIRUS } \\
\text { Nipah virus }\end{array}$} \\
\hline & $\begin{array}{c}\text { Middle East respiratory syndrome } \\
\text { coronavirus }\end{array}$ & $\begin{array}{c}\text { Severe acute respiratory } \\
\text { syndrome }\end{array}$ & $\begin{array}{l}\text { Severe acute respiratory } \\
\text { syndrome } 2 * *\end{array}$ & & \\
\hline Human functional receptor & Dipeptidyl peptidase 4 (DPP4 or D26 & $\begin{array}{l}\text { Angiotensin-converting enzyme } 2 \\
\text { (ACE2) and CD209L (L-SIGN) }\end{array}$ & $\begin{array}{c}\text { Angiotensin-converting enzyme } 2 \\
\text { (ACE2) host transmembrane serine } \\
\text { protease TMPRSS2 }\end{array}$ & $\begin{array}{l}\text { T cell immunoglobulin mucin } \\
\text { domain-1 (TIM-1) }\end{array}$ & $\begin{array}{l}\text { Ephrin B2 (membrane-bound } \\
\text { ligand for the EphB class of } \\
\text { receptor tyrosine kinases) }\end{array}$ \\
\hline Clinical characteristic & Bilateral pneumonia, diarrhoea & $\begin{array}{l}\text { Fever, bilateral pneumonia. Long } \\
\text { prodrome }\end{array}$ & $\begin{array}{l}\text { Peripheric bilateral pneumonia, } \\
\text { anosmia, dysgeusia. Increasing } \\
\text { report of neurological syndromes. }\end{array}$ & Hemorrhagic fever & $\begin{array}{c}\text { Encephalitis, acute respiratory } \\
\text { infection }\end{array}$ \\
\hline Geographical Origen & Saudi Arabia & Guandong, China & Wuhan, China & Africa & $\begin{array}{c}\text { Malaysia (1) } \\
\text { Bangladesh (2) }\end{array}$ \\
\hline Year of apparition & $\begin{array}{l}2012 \text { (ended in sporadic cases still } \\
\text { reported) }\end{array}$ & 2002 (ended in 2004) & December 2019 (ongoing) & 1967 & $\begin{array}{l}\text { (1) } 1998 \\
\text { (2) } 2001\end{array}$ \\
\hline Total of cases since apparition & 2,494 & 8,096 & $178,879,640$ & 587 & Approximately 845 \\
\hline Total deaths & 858 & 774 & $3,875,132$ & 475 & $>800$ \\
\hline CFR & $34 \%$ & $9.6 \%$ & $2.17 \% * * * *$ & $24-80 \%$ & $40-75 \%$ \\
\hline $\begin{array}{l}\text { Chiroptera associated } \\
\text { reservoirs }\end{array}$ & $\begin{array}{c}\text { Taphozous perforatus (Egyptian tomb bat), } \\
\text { Rhinopoma hardwickii (lesser mouse-tailed } \\
\text { bat) and Pipistrellus kuhlii (Kuhl's } \\
\text { pipistrelle) }\end{array}$ & $\begin{array}{l}\text { Giant horseshoe bat (Rhinolophus } \\
\text { ferrumequinum) }\end{array}$ & Horseshoe bats (Rhinolophus spp.) & Rousettus aegyptiacus & Pteropus hypomelanus \\
\hline Intermediated host & Camelus dromedaria (Camels) & Paguna larvata (Palm civet) & Pangolins? & $\begin{array}{l}\text { (Cercopithecus aethiops) African } \\
\text { green monkeys***, pigs? }\end{array}$ & $\begin{array}{l}\text { Pigs, horses, goats, sheep, cats } \\
\text { and dogs. }\end{array}$ \\
\hline Definitive treatment & No & No & No & No & No \\
\hline Vaccine & No & No & No & No & No \\
\hline
\end{tabular}

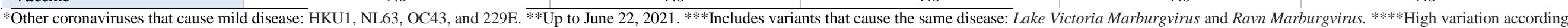
countries. 


\section{Porcine epidemic diarrhea virus}

The swine epidemic diarrhea disease caused by the Porcine Epidemic Diarrhea Virus (PEDV-CoV) belonging to the Betacoronavirus, was identified in England in 1971. It presents digestive symptoms associated with vomiting and diarrhea manifested in adult and young animals as well as a fatal outcome in newborn animals. The contagion occurred through the oronasal and fecal routes through having contact with secretions, fecal material, food, and water contaminated with the virus. Inter-species transmission occurred in the bat-pig relationship. During 2013, the disease remained registered in Asia, Europe, and America because of high losses since its outbreaks in susceptible pigs of all ages, which defines it as contagious (Piñeros and Mogollón Galvis, 2015; Simas et al., 2015; Banerjee et al., 2019) (Table 2).

According to studies in a recombinant CoV, possibly the PEDV could have been originated from the CoV of Scotophilus kuhlii (Han et al., 2019). Strains related to the coronavirus were detected in two Myotis horsfieldii bats, in Cambodia and Lao's People Democratic Republic, where the great diversity and presence of coronavirus genetically related PEDV strains that infect pigs, and cattle may promote transmission (Lacroix et al., 2017).

In a lineage of bats of the genus Scotophilus kuhlii in Guangxi, China, 11 strains related to the virus were identified (Lacroix et al., 2017; Han et al., 2019). Another study found a CoV with a high relation to PEDV-CoV from Brazil in Tadarida brasiliensis bats, which had a zoonotic impact on the appearance of new diseases in humans and animal populations (Piñeros and Mogollón Galvis, 2015). Porcine Epidemic Diarrhea Virus (PEDV) can infect kidney cells of specific brown bats (Eptesicus fuscus). However, replication in bat cells needs further studies. No clinical cases of PEDV in humans have been reported. However, it has been shown that it may infect embryonic kidney cells (Zhang et al., 2017; Banerjee et al., 2019).

\section{Swine acute diarrhea syndrome coronavirus}

The Swine Acute Diarrhea Syndrome (SADS CoV) is caused by a virus classified in the Alphacoronavirus, a type of coronavirus that emerged in 2017 in the Guangdong province, China (Health, 2018; Zhou et al., 2019). This virus causes an enteric disease that led to the death of 24,693 piglets in southern China. Over time, it was believed the virus has been completely eradicated until February 2019. A new outbreak in the east caused the death of 200,000 piglets, and its transmission mechanism has not yet been clarified. The main symptoms of infected animals were severe diarrhea and weight loss. The obtained results of post-mortem analysis were indicative of intestinal lesions (Zhou et al., 2018).

The SADS-CoV can infect bats, mice, hamsters, rats, gerbils, pigs, birds such as chickens, non-human primates, and potentially humans. However, its zoonotic effect is unknown, it was transmitted through the feces of infected animals or its natural reservoirs. In China, three outbreaks of this virus have been reported so far. It was found that horseshoe bats, such as Rhinolophus sinicus and Rhinolophus affinis, were the main reservoir bats for SARS-CoV Sarbecovirus, MERS-CoV Merbecovirus, and SADS-CoV Rhinacovirus in South East Asia (Wong et al., 2019; Yang et al., 2019). Studies in Guangdong, China, where stool samples of bats species were collected, showed the detection of coronavirus. In a study, authors found 58 positive samples out of 591, examined by the fecal smears and processed using molecular testing, which indicated that the bats of the species Rhinolophus sinicus, Rhinolophus affinis, and Rhinolophus rex were potential reservoirs of this coronavirus (Zhou et al., 2018) (Table 2).

\section{Middle East respiratory syndrome coronavirus}

The Middle East Respiratory Syndrome Coronavirus (MERS-CoV) is a linage C, zoonotic, betacoronavirus enveloped with a positive-sense RNA genome. It was isolated from a man's sputum in Jeddah, Saudi Arabia, in 2012 (Zaki et al., 2012). Subsequent cases and clusters of patients that developed a rapidly evolving bilateral pneumonia, respiratory failure, and death have been reported in the Arabian Peninsula. Since September 2012, a total of 2494 cases have been notified with 858 deaths associated with 27 countries. Studies have indicated that this virus had a case fatality rate of $35 \%$ (Banerjee et al., 2019).

Complete genome sequence analysis and serological data provided a piece of evidence for transmission from camels to humans. MERS-CoV-specific RNAs and antibodies were also detected in camels (Reusken et al., 2013; Azhar et al., 2014), so far, there are no antiviral effective treatments for limiting any human coronavirus infection. Fortunately, since late 2020, vaccines have become available against SARS-CoV-2 (St John et al., 2015; Abuhammad et al., 2017).

It is known that bats of the genus Taphozous perforatus (Egyptian tomb bat), Rhinopoma hardwickii (lesser mousetailed bat), and Pipistrellus kuhlii (Kuhl's pipistrelle) have acted as the natural reservoir of this virus for many years. Other studies claimed that the dromedary hair participated as an intermediary host for the spread of this virus, and its contact with the man (Banerjee et al., 2019; Fan et al., 2019; WHO, 2020c).

Camels are used in the Middle East for entertainment and transportation so that people can become infected through direct contact with infected camels, and they can shed the virus in their respiratory secretions (Azhar et al., 2014). They have also been detected in camel milk, then there is a risk of infection through consumption of unpasteurized camel milk (Reusken et al., 2014; Han et al., 2015). 
The functional receptor of MERS-CoV is Dipeptidyl Peptidase 4 (DPP4 or CD26), which is present on the surface of the human non-ciliated bronchial epithelial cells (Lu et al., 2013). The receptor can also be found on bats' cells (Cui et al., 2013). Even more, there are descriptions of novel bat coronavirus in South China that attach to this receptor; the clinical implications of these results are unknown (Luo et al., 2018). A study reported that the use of the receptor by the MERS-CoV was different from that used by SARS-CoV and by SARS-CoV-2 (ACE2). The MERS-CoV receptor is conserved and can replicate in both bat cells and human cells (Müller et al., 2012; Han et al., 2015) (Table 2).

\section{Severe acute respiratory syndrome coronavirus}

The Severe Acute Respiratory Syndrome Coronavirus (SARS-CoV) is a linage b Betacoronavirus and the MERSCoVs (Maganga et al., 2020). It was based in Foshan, province of Guangdong, China in November 2002 (Fan et al., 2019). The index case was a medical doctor from the province of Guandong who made a trip to Hong Kong Special Administrative Region of the People's Republic of China, five days after the onset of symptoms. After that secondary cases appeared in the city and Singapore, Thailand, Vietnam, and Canada. All the index cases were from those countries where travelers returned from Hong Kong (Tsang et al., 2003). From the first cases, a novel coronavirus was isolated (Drosten et al., 2003). Following that it reached 33 countries and 5 continents, including North America and Europe, causing a global pandemic that lasted eight months, and led to 8096 cases with 774 deaths, reaching a case-fatality rate of $9.6 \%$. The transmission occurred through respiratory drops, micro saliva, or direct contact with the mucous membranes of patients. Extraordinary efforts were made to contain these emerging conditions were deployed globally, including travel advisories by the World Health Organization (WHO) that in consequence led to the end of the epidemic in the first half of 2004 (Vaqué Rafart, 2005).

The SARS is presented as the first epidemic disease of the twenty-first century. It is known that its origin was the wet markets of Guandong, China, where the interaction with fluids and blood of different animals facilitated the propagation. Some studies indicated that the Himalayan palm civet and the palm civet o masked palm civet (Paguna larvata) were the intermediaries of this virus as a reservoir host as same as the giant horseshoe bat (Rhinolophus ferrumequinum) (Wang et al., 2006; Cleri et al., 2010).

The SARS-CoV produced unusual pneumonia because it had a prolonged prodrome with influenza-like symptoms. The patients develop the respiratory phase with progressive pulmonary infiltrates and respiratory failure. From early in the research, the virus has efficiently replicated in vitro (Sims et al., 2008). The functional receptors for SARS-CoV are Angiotensin-converting enzyme 2 (ACE2) and CD209L (L-SIGN) (Jeffers et al., 2004).

The SARS-CoV's genetic components circulated among the various bats' species that share the same cave and the opportunity for a new resurgence (Banerjee et al., 2019; Wong et al., 2019). The SARS virus survives for at least two to four days in feces, and two to three days on dry surfaces at room temperature (Rabenau et al., 2005). The transmission from person to person by direct or indirect contact of the mucous membranes with drops was the primary mode of spread of the pandemic produced in health centers, workplaces, homes, public transport, and air travel; the latter facilitated its rapid worldwide diffusion (Seto et al., 2003; Cheng et al., 2007). The SARS-CoV was detected in feces, urine, and respiratory secretions (Chan et al., 2004). Intra-hospital transmission of the virus was facilitated by nebulizers, intubation, or cardiopulmonary resuscitation in patients with SARS generated by many infectious droplets (Lee et al., 2003; Christian et al., 2004; Loon et al., 2004).

Regarding phylogenetic and viral diversity analyses, studies conducted in Africa, Asia, and Latin America (Peru, Bolivia, Brazil, and Mexico) indicated that intra-genus transmission of bats was higher in Africa and Asia (Health, 2018). The study was also able to confirm that the abundance of the virus was related to many bats (Health, 2018).

A study of an in-hospital outbreak at a community hospital in Toronto on February 23, 2003, indicated that cases of this virus had the age range from 21 months to 86 years, $60.2 \%$ of whom were women, and total death of 17 cases. Of the cases identified, $36.7 \%$ were hospital personnel. Other cases were locally transmitted or linked to imported SARS cases from other places $(29.6 \%)$, hospitalized patients $(14.1 \%)$, visitors $(14.1 \%)$, or other health staff $(5.5 \%)$. Of a total of 128 cases, $120(93.8 \%)$ had contact with a SARS-positive case or a place where there was a known case of infection (Varia et al., 2003) (Table 2).

It is essential to know that bats and their products are used in food markets, and as traditional medicine, the feces of bats are used in the south from China and Asia, and consequently, it provides a constant human exposure source to bats and their tissues (Bonilla-Aldana et al., 2020e; Dhama et al., 2020a; Dhama et al., 2020b).

\section{Severe acute respiratory syndrome coronavirus 2}

Severe Acute Respiratory Syndrome Coronavirus 2 (SARS-CoV-2), the etiological agent of COVID-19, belongs to the subgenus's genus Betacoronavirus Sarbecovirus (same subgenus for SARS-CoV). It has affected the world since January 2020, affecting 210 countries and territories. In December 2019, a cluster of pneumonia with epidemiological nexus with an open-air-live animal market in Wuhan, China, was reported. A novel coronavirus was isolated and named SARS-CoV-2 by the International Committee on Taxonomy Viruses (ICTV). As of June 22, 2021, it has left a balance of 
178,879,640 confirmed cases and 3,875,132 deaths worldwide, but these figures continued to increase (Alanagreh et al., 2020; WHO, 2020a; Tiwari et al., 2020), fortunately 2.76 billion doses of vaccine have been administered. The outbreak was discovered in the Wuhan market, verifying that all the samples obtained from the animals were positive for SARSCoV-2. This virus had been circulating since November, 2019. On December 1, 2019, the first registered case was found in an elderly man (Mackenzie and Smith, 2020; Yu et al., 2020). Subsequently, significant attempts have been rendered to detect the reservoirs and intermediate host of this emerging infectious disease.

Comparisons revealed that the bat $\mathrm{CoV}$ is approximately $79 \%$ similar to SARS-CoV at the nucleotide level. Although the MERS and SARS viruses are related to SARS-CoV-2, they have very notable biological differences. SARS-CoV 2 is much more infectious and has a remarkable capacity for local and global spread. It has been taken as a priority to determine the virological characteristics related to transmission. The respiratory pathogen has a relatively high virulence that can jump the barrier species (Chinazzi et al., 2020; Zhang and Holmes, 2020). The bats' role as a zoonotic origin is unknown. The viruses present an association with SARS-CoV-2 were sampled in Yunnan province more than $1,500 \mathrm{~km}$ from Wuhan (Wrapp et al., 2020). In a recent publication, a bat coronavirus, RaTG13, was found in Rhinolophus affinis, showed $96 \%$ genomic similarity to SARS-CoV-2. However, it does not bind efficiently to the human receptor ACE2 (Leitner and Kumar, 2020).

The bat is reported as the reservoir source, but it needs an intermediate host for SARS-CoV-2 to infect humans. A conducted study showed that SARS-CoV-2 replicates poorly in pigs, chickens, and ducks (Flores-Alanis et al., 2020). The pangolins (Pholidota) have been studied as a relevant intermediate host for SARS-CoV-2, with genetic analysis of pangolin CoV, MP789, showing similarities in receptor domains, suggesting an ancestral jump among bats (FloresAlanis et al., 2020), humans, and pangolins (Fischer et al., 2020; Xiao et al., 2020; Zhang et al., 2020). However, if bats are susceptible to contracting the virus, ferrets, canids, and cats are still possible to directly infect humans (Damas et al., 2020; Leitner and Kumar, 2020; Tiwari et al., 2020). Researchers have proposed the potential risk of reverse zoonotic transmission to bats (anthropozoonosis), because of the magnitude of this historic pandemic and the intricate relationship of SARS-CoV-2 and Chiroptera. Researchers have proposed the potential risk of reverse zoonotic transmission from humans to bats (anthropozoonosis) of the SARS-CoV-2 (Franklin and Bevins, 2020; Olival et al., 2020).

The infection can be acquired by inhaling droplets that can spread from one to two, or by touching contaminated surfaces which can remain viable for several days with favorable atmospheric conditions. However, the viruses are destroyed with hypochlorite sodium products, hydrogen, peroxide, among other substances. The virus is also present in feces and contamination of the water supply leading to the transmission through the oral route (Chen et al., 2020; WHO, 2020b; Kampf et al., 2020).

All people are theoretically susceptible; the large droplets come from the coughs and sneezes of symptomatic or asymptomatic patients before the clinical signs appear, causing severe respiratory diseases such as pulmonary failure and pneumonia. However, the severity of COVID19 is unusually selective, rises with age and coexisting health conditions, including, chronic kidney disease, diabetes mellitus, obesity, smoking, and hypertension. There is also increasing evidence about ethnicity and income for the susceptibility of infection and poorer prognosis (de Lusignan et al., 2020). Human genetic factors, such as polymorphism of the host transmembrane serine protease (TMPRSS2) and ACE2 receptor have been proposed (Hou et al., 2020). Post-placental transmission in women has not yet been clearly described. Studies have shown that higher viral loads are found in the nasal cavity than the throat, without differentiating between symptomatic and asymptomatic people. Patients can infect other humans for as long as symptoms last and even after clinical recovery (Rothe et al., 2020; Singhal, 2020; Zou et al., 2020) (Table 2).

\section{CONCLUSIONS}

Bats are potential reservoirs of many viruses, including coronaviruses, but direct transmission to humans has not been demonstrated so far since it requires an intermediate host (Joffrin et al., 2020). Recently, in Peru, the complete genome sequence of an Alphacoronavirus isolated from vampire bats (Desmodus rotundus, family Phyllostomidae) from the Amazonas region was reported (Bergner et al., 2020).

Research of coronavirus in bats have become an urgent problem, so it is essential to be able to detect early warning signs, and minimize the subsequent outbreaks given by them in places like Egypt, Oman, Qatar, Saudi Arabia, the Middle East, Africa, and South Asia, have found camelids with the virus mentioned above, which their human-animal transmission can be generated by direct or indirect contact with infected animals (Banerjee et al., 2019; Fan et al., 2019; WHO, 2020c). More research is needed to clarify and understand the susceptibility of infection and variable outcomes.

However, there are still some questions that are left unanswered which necessitates the need for more deep studies addressing the effect of coronaviruses on animals and humans. In 2019, a coronavirus mutation from previous years was presented, and people would be exposed to a higher risk of new pandemics caused by CoVs. Thus, it is equally important to know which intermediate hosts are the means of transmission of bats to human beings. 


\section{DECLARATIONS}

\section{Acknowledgments}

Present paper was developed as a part of the classes of Research Methods (Asignatura Metodología de la Investigación) of the School of Veterinary Medicine and Zootechnics, Fundación Universitaria Autónoma de las Américas, Pereira, Risaralda, Colombia, 2020.

\section{Authors' Contributions}

DKBA and AJRM conceived the review, developed the preliminary search strategy, and drafted the manuscript. SDJD, CTO, PJS, VGM, and JLBA refined the search strategy by conducting iterative database queries and incorporating new search terms. SDJD, CTO, PJS, VGM, and JLBA searched and collected the articles. AJRM and DKBA conducted the quality assessment. All authors have critically reviewed this manuscript for relevant intellectual contributions. All the authors read and approved the final submitted version of the paper.

\section{Conflicts of interest}

All authors report no potential conflicts.

\section{Funding Source}

The current article was funded by the Dirección de Investigación Científica, Humanística y Tecnológica (2-05-0101), National Autonomous University of Honduras, Tegucigalpa, MDC, Honduras, Central America.

\section{Ethical considerations}

Ethical issues (including plagiarism, consent to publish, double publication and/or submission, and redundancy) have been checked by the authors.

\section{REFERENCES}

Abuhammad A, Al-Aqtash RaA, Anson BJ, Mesecar AD, and Taha MO (2017). Computational modeling of the bat hku4 coronavirus 3cl(pro) inhibitors as a tool for the development of antivirals against the emerging middle east respiratory syndrome (MERS) coronavirus. Journal of Molecular Recognition, 30(11): e2644. DOI: http://www.doi.org/10.1002/jmr.2644

Ahlén I, Baagøe HJ, and Bach L (2009). Behavior of Scandinavian bats during migration and foraging at sea. Journal of Mammalogy, 90(6): 13181323. DOI: http://www.doi.org/10.1644/09-MAMM-S-223R.1

Ahn DG, Shin HJ, Kim MH, Lee S, Kim HS, Myoung J, Kim BT, and Kim SJ (2020). Current status of epidemiology, diagnosis, therapeutics, and vaccines for novel coronavirus disease 2019 (covid-19). Journal of Microbiology and Biotechnology, 30(3): 313-324. DOI: http://www.doi.org/10.4014/jmb.2003.03011

Alanagreh La, Alzoughool F, and Atoum M (2020). The human coronavirus disease covid-19: Its origin, characteristics, and insights into potential drugs and its mechanisms. Pathogens, 9(5): 331. DOI: http://www.doi.org/10.3390/pathogens9050331

Allen LC, Turmelle AS, Mendonça MT, Navara KJ, Kunz TH, and McCracken GF (2009). Roosting ecology and variation in adaptive and innate immune system function in the Brazilian free-tailed bat (Tadarida brasiliensis). Journal of Comparative Physiology B, 179(3): 315-323. DOI: http://www.doi.org/10.1007/s00360-008-0315-3

Amador LI, Moyers Arévalo RL, Almeida FC, Catalano SA, and Giannini NP (2018). Bat systematics in the light of unconstrained analyses of a comprehensive molecular supermatrix. Journal of Mammalian Evolution, 25(1): 37-70. DOI: http://www.doi.org/10.1007/s10914-016-9363-8

Azhar EI, El-Kafrawy SA, Farraj SA, Hassan AM, Al-Saeed MS, Hashem AM, and Madani TA (2014). Evidence for camel-to-human transmission of MERS coronavirus. New England Journal of Medicine, 370(26): 2499-2505. DOI: http://www.doi.org/10.1056/NEJMoa1401505

Banerjee A, Kulcsar K, Misra V, Frieman M, and Mossman K (2019). Bats and coronaviruses. Viruses, 11(1): Article number 41. DOI: http://www.doi.org/10.3390/v11010041

Banerjee A, Misra V, Schountz T, and Baker ML (2018). Tools to study pathogen-host interactions in bats. Virus Research, 248: 5-12. DOI: http://www.doi.org/ 10.1016/j.virusres.2018.02.013

Basu-Ray I, Almaddah NK, Adeboye A, and Soos MP (2020). Cardiac manifestations of coronavirus (Covid-19). Statpearls, StatPearls Publishing.

Bergner LM, Orton RJ, and Streicker DG (2020). Complete genome sequence of an alphacoronavirus from common vampire bats in Peru. Microbiol Resource Announcements, 9(34): e00742-20. DOI: http://www.doi.org/10.1128/MRA.00742-20

Bonilla-Aldana DK, Dhama K, and Rodriguez-Morales AJ (2020a). Revisiting the one health approach in the context of covid-19: A look into the ecology of this emerging disease. Advances in Animal and Veterinary Sciences, 8(3): 234-237. Available at: http://nexusacademicpublishers.com/uploads/files/AAVS_8_3_234-237.pdf

Bonilla-Aldana DK, Holguin-Rivera Y, Cortes-Bonilla I, Cardona-Trujillo MC, Garcia-Barco A, Bedoya-Arias HA, Rabaan AA, Sah R, and Rodriguez-Morales AJ (2020b). Coronavirus infections reported by promed, february 2000-january 2020. Travel Medicine and Infectious Disease, 39: Article number 101575. DOI: http://www.doi.org/10.1016/j.tmaid.2020.101575

Bonilla-Aldana DK, Jimenez-Diaz SD, Arango-Duque JS, Aguirre-Florez M, Balbin-Ramon GJ, Paniz-Mondolfi A, Suarez JA, Pachar MR, PerezGarcia LA, Delgado-Noguera LA et al. (2021). Bats in ecosystems and their wide spectrum of viral infectious potential threats: SARS-CoV-2 and other emerging viruses. International Journal of Infectious Diseases, 102: 87-96. DOI: http://www.doi.org/10.1016/j.ijid.2020.08.050

Bonilla-Aldana DK, Jimenez-Diaz SD, Patel SK, Dhama K, Rabaan AA, Sah R, Sierra M, Zambrano LI, Arteaga-Livias K, and Rodriguez-Morales AJ (2020c). Importance of bats in wildlife: Not just carriers of pandemic SARS-CoV-2 and other viruses. Journal of Pure and Applied Microbiology, 14(1): 709-712. DOI: http://www.doi.org/10.22207/jpam.14.Spl1.05 
Bonilla-Aldana DK, Quintero-Rada K, Montoya-Posada JP, Ramirez-Ocampo S, Paniz-Mondolfi A, Rabaan AA, Sah R, and Rodriguez-Morales AJ (2020d). SARS-CoV-2, MERS-CoV and now the 2019-novel CoV: Have we investigated enough about coronaviruses? - a bibliometric analysis. Travel Medicine and Infectious Disease, 33: Article number101566. DOI: http://www.doi.org/10.1016/j.tmaid.2020.101566

Bonilla-Aldana DK, Villamil-Gómez WE, Rabaan AA, and Rodriguez-Morales AJ (2020e). Una nueva zoonosis viral de preocupación global: Covid19, enfermedad por coronavirus 2019. Iatreia, 33(2): 107-110.

Calisher CH, Childs JE, Field HE, Holmes KV, and Schountz T (2006). Bats: Important reservoir hosts of emerging viruses. Clinical Microbiology Reviews, 19(3): 531-545. DOI: http://www.doi.org/10.1128/CMR.00017-06

Chan WM, Yuen KSC, Fan DSP, Lam DSC, Chan PKS, and Sung JJY (2004). Tears and conjunctival scrapings for coronavirus in patients with sars. British Journal of Ophthalmology, 88(7): 968-969. DOI: http://www.doi.org/10.1136/bjo.2003.039461

Chen H, Guo J, Wang C, Luo F, Yu X, Zhang W, Li J, Zhao D, Xu D, Gong Q et al. (2020). Clinical characteristics and intrauterine vertical transmission potential of covid-19 infection in nine pregnant women: A retrospective review of medical records. The Lancet, 395: 809-815. DOI: http://www.doi.org/10.1016/S0140-6736(20)30360-3

Cheng VCC, Lau SKP, Woo PCY, and Yuen KY (2007). Severe acute respiratory syndrome coronavirus as an agent of emerging and reemerging infection. Clinical Microbiology Reviews, 20(4): 660-694. DOI: http://www.doi.org/10.1128/CMR.00023-07

Chinazzi M, Davis JT, Ajelli M, Gioannini C, Litvinova M, Merler S, Piontti APY, Rossi L, Sun K, Viboud C et al. (2020). The effect of travel restrictions on the spread of the 2019 novel coronavirus (2019-Nov) outbreak. Med Rxiv, 2020.2002.2009.20021261. DOI: http://www.doi.org/10.1101/2020.02.09.20021261

Christian MD, Loutfy M, McDonald LC, Martinez KF, Ofner M, Wong T, Wallington T, Gold WL, Mederski B, Green K et al. (2004). Possible sars coronavirus transmission during cardiopulmonary resuscitation. Emerging Infectious Diseases, 10(2): 287-293. DOI: http://www.doi.org/10.3201/eid1002.030700

Cleri DJ, Ricketti AJ, and Vernaleo JR (2010). Severe acute respiratory syndrome (sars). Infectious Disease Clinics, 24(1): 175-202. DOI: http://www.doi.org/10.1016/j.idc.2009.10.005

Cui J, Eden JS, Holmes EC, and Wang LF (2013). Adaptive evolution of bat dipeptidyl peptidase 4 (dpp4): Implications for the origin and emergence of middle east respiratory syndrome coronavirus. Virology Journal, 10: Article number 304. DOI: http://www.doi.org/10.1186/1743-422X-10$\underline{304}$

Damas J, Hughes GM, Keough KC, Painter CA, Persky NS, Corbo M, Hiller M, Koepfli KP, Pfenning AR, Zhao H et al. (2020). Broad host range of Sars-Cov-2 predicted by comparative and structural analysis of ace 2 in vertebrates. Proceedings of the National Academy of Sciences of the USA, 117(36): 22311-22322. DOI: http://www.doi.org/10.1073/pnas.2010146117

de Lusignan S, Dorward J, Correa A, Jones N, Akinyemi O, Amirthalingam G, Andrews N, Byford R, Dabrera G, Elliot A et al. (2020). Risk factors for Sars-Cov-2 among patients in the oxford royal college of general practitioners research and surveillance centre primary care network: A crosssectional study. Lancet Infectious Diseases, 20(9): 1034-1042. DOI: http://www.doi.org/10.1016/S1473-3099(20)30371-6

Dhama K, Khan S, Tiwari R, Sircar S, Bhat S, Malik YS, Singh KP, Chaicumpa W, Bonilla-Aldana DK, and Rodriguez-Morales AJ (2020a). Coronavirus disease 2019-covid-19. Clinical Microbiology Reviews, 33(4): e00028-20. DOI: http://www.doi.org/10.1128/CMR.00028-20

Dhama K, Patel SK, Sharun K, Pathak M, Tiwari R, Yatoo MI, Malik YS, Sah R, Rabaan AA, Panwar PK et al. (2020b). SARS-CoV-2 jumping the species barrier: Zoonotic lessons from sars, MERS, and recent advances to combat this pandemic virus. Travel Medicine and Infectious Diseases, 37: Article number 101830. DOI: http://www.doi.org/10.1016/j.tmaid.2020.101830

Dobson AP (2005). What links bats to emerging infectious diseases? Science, 310: 628-629. DOI: http://www.doi.org/10.1126/science.1120872

Dos Santos Bezerra R, Valenca IN, de Cassia Ruy P, Ximenez JPB, da Silva Junior WA, Covas DT, Kashima S, and Slavov SN (2020). The novel coronavirus SARS-CoV-2: From a zoonotic infection to coronavirus disease 2019. Journal of Medical Virology, 92(11): 2607-2615. DOI: http://www.doi.org/10.1002/jmv.26072

Drosten C, Gunther S, Preiser W, van der Werf S, Brodt HR, Becker S, Rabenau H, Panning M, Kolesnikova L, Fouchier RA et al. (2003). Identification of a novel coronavirus in patients with severe acute respiratory syndrome. New England Journal of Medicine, 348(20): 1967-1976. DOI: http://www.doi.org/10.1056/NEJMoa030747

Eick GN, Jacobs DS, and Matthee CA (2005). A nuclear DNA phylogenetic perspective on the evolution of echolocation and historical biogeography of extant bats (Chiroptera). Molecular Biology and Evolution, 22(9): 1869-1886. DOI: http://www.doi.org/10.1093/molbev/msi180

Fan Y, Zhao K, Shi ZL, and Zhou P (2019). Bat coronaviruses in China. Viruses, 11(3): Article number 210. DOI: http://www.doi.org/10.3390/v11030210

Fischer H, Tschachler E, and Eckhart L (2020). Pangolins lack ifih1/mda5, a cytoplasmic RNA sensor that initiates innate immune defense upon coronavirus infection. Frontiers in Immunology, 11: Article number 939. DOI: http://www.doi.org/10.3389/fimmu.2020.00939

Fleming TH (2019). Bat migration. Encyclopedia of Animal Behavior, pp. 605-610. DOI: http://www.doi.org/10.1016/B978-0-12-809633-8.20764-4

Flies AS, and Woods GM (2019). Wild immunology-the answers are out there. Frontiers in Immunology, 10: 126-126. DOI: http://www.doi.org/10.3389/fimmu.2019.00126

Flores-Alanis A, Sandner-Miranda L, Delgado G, Cravioto A, and Morales-Espinosa R (2020). The receptor binding domain of SARS-CoV-2 spike protein is the result of an ancestral recombination between the bat-CoV ratg13 and the pangolin-CoV mp789. BMC Research Notes, 13(1): Article number 398. DOI: http://www.doi.org/10.1186/s13104-020-05242-8

Franklin AB, and Bevins SN (2020). Spillover of SARS-CoV-2 into novel wild hosts in North America: A conceptual model for perpetuation of the pathogen. Science of the Total Environ, 733: Article ID 139358. DOI: http://www.doi.org/10.1016/j.scitotenv.2020.139358

George DB, Webb CT, Farnsworth ML, O'Shea TJ, Bowen RA, Smith DL, Stanley TR, Ellison LE, and Rupprecht CE (2011). Host and viral ecology determine bat rabies seasonality and maintenance. Proceedings of the National Academy of Sciences of the USA, 108(25): 10208-10213. DOI: http://www.doi.org/10.1073/pnas.1010875108

Han HJ, Wen Hl, Zhou CM, Chen FF, Luo LM, Liu JW, and Yu XJ (2015). Bats as reservoirs of severe emerging infectious diseases. Virus Research, 205: 1-6. DOI: http://www.doi.org/10.1016/j.virusres.2015.05.006

Han Y, Du J, Su H, Zhang J, Zhu G, Zhang S, Wu Z, and Jin Q (2019). Identification of diverse bat alphacoronaviruses and betacoronaviruses in China provides new insights into the evolution and origin of coronavirus-related diseases. Frontiers in Microbiology, 10: 1900-1900. DOI: http://www.doi.org/10.3389/fmicb.2019.01900

Health NI (2018). New coronavirus emerges from bats in China, devastates young swine. Available at: https://www.nih.gov/news-events/newsreleases/new-coronavirus-emerges-bats-china-devastates-young-swine

Hedenström A (2009). Optimal migration strategies in bats. Journal of Mammalogy, 90(6): 1298-1309. DOI: http://www.doi.org/10.1644/09-MAMMS-075R2.1

Hou Y, Zhao J, Martin W, Kallianpur A, Chung MK, Jehi L, Sharifi N, Erzurum S, Eng C, and Cheng F (2020). New insights into genetic susceptibility of covid-19: An ace2 and tmprss2 polymorphism analysis. BMC Medicine, 18(1): Article number 216. DOI: http://www.doi.org/10.1186/s12916-020-01673-z

To cite this paper: Bonilla-Aldana DK, Toro-Ortiz C, Jimenez-Salazar P, Guevara-Manso V, Jimenez-Diaz SD, Bonilla-Aldana JL, Gutierrez-Grajales EJ, Pecho-Silva S, Paniz-Mondolfi A, Suárez JA, Pachar MR, Martinez-Pulgarin DF, Zambrano LI, Soler-Tovar D, Rodriguez-Morales AJ, and Mattar S (2021). The Broad Range of Coronaviruses Co-existing in Chiropteran: Implications for One Health. World Vet. J., 11 (2): 170-180. 
Huong NQ, Nga NTT, Long NV, Luu BD, Latinne A, Pruvot M, Phuong NT, Quang LTV, Hung VV, Lan NT et al. (2020). Coronavirus testing indicates transmission risk increases along wildlife supply chains for human consumption in Vietnam, 2013-2014. PLoS ONE, 15(8): e0237129. DOI: http://www.doi.org/10.1371/journal.pone.0237129

Jeffers SA, Tusell SM, Gillim-Ross L, Hemmila EM, Achenbach JE, Babcock GJ, Thomas WD, Thackray LB, Young MD, Mason RJ et al. (2004), Cd2091 (1-sign) is a receptor for severe acute respiratory syndrome coronavirus. Proceedings of the National Academy of Sciences of the USA, 101(44): 15748-15753. DOI: http://www.doi.org/10.1073/pnas.0403812101

Joffrin L, Goodman SM, Wilkinson DA, Ramasindrazana B, Lagadec E, Gomard Y, Le Minter G, Dos Santos A, Corrie Schoeman M, Sookhareea R et al. (2020). Bat coronavirus phylogeography in the western Indian ocean. Scientific Reports, 10(1): Article number 6873. DOI: http://www.doi.org/10.1038/s41598-020-63799-7

Kampf G, Todt D, Pfaender S, and Steinmann E (2020). Persistence of coronaviruses on inanimate surfaces and their inactivation with biocidal agents. Journal of Hospital Infection, 104(3): 246-251. DOI: http://www.doi.org/10.1016/j.jhin.2020.01.022

Kasso M, and Balakrishnan M (2013). Ecological and economic importance of bats (order Chiroptera). ISRN Biodiversity, Article ID: 187415. DOI: http://www.doi.org/10.1155/2013/187415

King AMQ, Adams MJ, Carstens EB et al (2012). Family-coronaviridae. In: King AMQ, Adams MJ, Carstens EB et al. (eds) Virus taxonomy. San Diego: Elsevier, pp. 806-828. DOI: http://www.doi.org/10.1016/B978-0-12-384684-6.00136-1

Lacroix A, Duong V, Hul V, San S, Davun H, Omaliss K, Chea S, Hassanin A, Theppangna W, Silithammavong S et al. (2017). Genetic diversity of coronaviruses in bats in lao pdr and Cambodia. Infection, Genetics, and Evolution, 48: 10-18. DOI: http://www.doi.org/10.1016/j.meegid.2016.11.029

Lee N, Hui D, Wu A, Chan P, Cameron P, Joynt GM, Ahuja A, Yung MY, Leung CB, To KF et al. (2003). A major outbreak of severe acute respiratory syndrome in hong kong. New England Journal of Medicine, 348(20): 1986-1994. DOI: http://www.doi.org/10.1056/NEJMoa030685

Leitner T, and Kumar S (2020). Where did SARS-CoV-2 come from? Molecular Biology and Evolution, 37(9): 2463-2464. DOI: http://www.doi.org/10.1093/molbev/msaa162

Loon SC, Teoh SCB, Oon LLE, Se-Thoe SY, Ling AE, Leo YS, and Leong HN (2004). The severe acute respiratory syndrome coronavirus in tears. British Journal of Ophthalmology, 88(7): 861-863. DOI: http://www.doi.org/10.1136/bjo.2003.035931

Lu G, Hu Y, Wang Q, Qi J, Gao F, Li Y, Zhang Y, Zhang W, Yuan Y, Bao J et al. (2013). Molecular basis of binding between novel human coronavirus MERS-CoV and its receptor cd26. Nature, 500: 227-231. DOI: http://www.doi.org/10.1038/nature12328

Luo CM, Wang N, Yang XL, Liu HZ, Zhang W, Li B, Hu B, Peng C, Geng QB, Zhu GJ et al. (2018). Discovery of novel bat coronaviruses in South China that use the same receptor as middle east respiratory syndrome coronavirus. Journal of Virology, 92(13): e00116-18. DOI: http://www.doi.org/10.1128/JVI.00116-18

Mackenzie JS, and Smith DW (2020). Covid-19: A novel zoonotic disease caused by a coronavirus from China: What we know and what we don't. Microbiology Austin, MA20013. DOI: http://www.doi.org/10.1071/MA20013

Mackenzie JS, Childs JE, Field HE, Wang LF, and Breed AC (2016). The role of bats as reservoir hosts of emerging neuroviruses. Neurotropic Viral Infections, pp. 403-454. DOI: http://www.doi.org/10.1007/978-3-319-33189-8_12

Maganga GD, Pinto A, Mombo IM, Madjitobaye M, Mbeang Beyeme AM, Boundenga L, Ar Gouilh M, N'Dilimabaka N, Drexler JF, Drosten C et al. (2020). Genetic diversity and ecology of coronaviruses hosted by cave-dwelling bats in Gabon. Scientific Reports, 10(1): Article number 7314. DOI: http://www.doi.org/10.1038/s41598-020-64159-1

Mollentze N, and Streicker DG (2020). Viral zoonotic risk is homogenous among taxonomic orders of mammalian and avian reservoir hosts. Proceedings of the National Academy of Sciences of the USA, 117(17): 9423-9430. DOI: http://www.doi.org/10.1073/pnas.1919176117

Moratelli R, and Calisher CH (2015a). Bats and zoonotic viruses: Can we confidently link bats with emerging deadly viruses? Memorias do Instituto Oswaldo Cruz, 110(1): 1-22. DOI: http://www.doi.org/10.1590/0074-02760150048

Moratelli R, and Calisher CH (2015b). Bats and zoonotic viruses: Can we confidently link bats with emerging deadly viruses? Mem Inst Oswaldo Cruz, 110(1): 1-22. DOI: http://www.doi.org/10.1590/0074-02760150048

Müller MA, Raj VS, Muth D, Meyer B, Kallies S, Smits SL, Wollny R, Bestebroer TM, Specht S, Suliman T et al. (2012). Human coronavirus emc does not require the sars-coronavirus receptor and maintains broad replicative capability in mammalian cell lines. mBio, 3(6): 515-512. DOI: http://www.doi.org/10.1128/mBio.00515-12

Olival KJ, Cryan PM, Amman BR, Baric RS, Blehert DS, Brook CE, Calisher CH, Castle KT, Coleman JTH, Daszak P et al. (2020). Possibility for reverse zoonotic transmission of SARS-CoV-2 to free-ranging wildlife: A case study of bats. PLoS Pathogens, 16(9): e1008758. DOI: http://www.doi.org/10.1371/journal.ppat.1008758

Piñeros R, and Mogollón Galvis JD (2015). Coronavirus en porcinos: Importancia y presentación del virus de la diarrea epidémica porcina (pedv) en Colombia. Revista de Medicina Veterinaria, pp. 73-89. Available at: http://www.scielo.org.co/scielo.php?pid=S012293542015000100008\&script=sci_abstract\&tlng=es

Rabenau HF, Cinatl J, Morgenstern B, Bauer G, Preiser W, and Doerr HW (2005). Stability and inactivation of sars coronavirus. Medical Microbiology and Immunology, 194: 1-6. DOI: http://www.doi.org/10.1007/s00430-004-0219-0

Reusken CB, Farag EA, Jonges M, Godeke GJ, El-Sayed AM, Pas SD, Raj VS, Mohran KA, Moussa HA, Ghobashy H et al. (2014). Middle east respiratory syndrome coronavirus (MERS-CoV) RNA and neutralising antibodies in milk collected according to local customs from dromedary camels, Qatar, April 2014. Eurosurveillance, 19(23): Article number 20829. DOI: http://www.doi.org/10.2807/1560-7917.ES2014.19.23.20829

Reusken CBEM, Haagmans BL, Müller MA, Gutierrez C, Godeke GJ, Meyer B, Muth D, Raj VS, Vries LSD, Corman VM et al. (2013). Middle east respiratory syndrome coronavirus neutralising serum antibodies in dromedary camels: A comparative serological study. The Lancet Infectious Diseases, 13(10): 859-866. DOI: http://www.doi.org/10.1016/S1473-3099(13)70164-6

Rodriguez-Morales AJ, MacGregor K, Kanagarajah S, Patel D, and Schlagenhauf P (2020). Going global - travel and the 2019 novel coronavirus. Travel Medicine and Infectious Diseases, 33: Article number 101578. DOI: http://www.doi.org/10.1016/j.tmaid.2020.101578

Rothe C, Schunk M, Sothmann P, Bretzel G, Froeschl G, Wallrauch C, Zimmer T, Thiel V, Janke C, Guggemos W et al. (2020). Transmission of 2019ncov infection from an asymptomatic contact in Germany. New England Journal of Medicine, 382(10): 970-971. DOI: http://www.doi.org/10.1056/NEJMc2001468

Schountz T (2014). Immunology of bats and their viruses: Challenges and opportunities. Viruses, 6(12): 4880-4901. DOI: http://www.doi.org/10.3390/v6124880

Seto WH, Tsang D, Yung RWH, Ching TY, Ng TK, Ho M, Ho LM, Peiris JSM, and Advisors of Expert SgoHA (2003). Effectiveness of precautions against droplets and contact in prevention of nosocomial transmission of severe acute respiratory syndrome (sars). Lancet, 361(9368): 1519-1520. DOI: http://www.doi.org/10.1016/s0140-6736(03)13168-6

Simas PVM, Barnabé ACdS, Durães-Carvalho R, Neto DFdL, Caserta LC, Artacho L, Jacomassa FAF, Martini MC, Bianchi Dos Santos MMA, Felippe PAN et al. (2015). Bat coronavirus in brazil related to appalachian ridge and porcine epidemic diarrhea viruses. Emerging Infectious Diseases, 21(4): 729-731. DOI: http://www.doi.org/10.3201/eid2104.141783

To cite this paper: Bonilla-Aldana DK, Toro-Ortiz C, Jimenez-Salazar P, Guevara-Manso V, Jimenez-Diaz SD, Bonilla-Aldana JL, Gutierrez-Grajales EJ, Pecho-Silva S, Paniz-Mondolfi A, Suárez JA, Pachar MR, Martinez-Pulgarin DF, Zambrano LI, Soler-Tovar D, Rodriguez-Morales AJ, and Mattar S (2021). The Broad Range of Coronaviruses Co-existing in Chiropteran: Implications for One Health. World Vet. J., 11 (2): 170-180. 
Simmons NB, Seymour KL, Habersetzer J, and Gunnell GF (2008). Primitive early eocene bat from wyoming and the evolution of flight and echolocation. Nature, 451(7180): 818-821. DOI: http://www.doi.org/10.1038/nature06549

Sims AC, Burkett SE, Yount B, and Pickles RJ (2008). SARS-CoV replication and pathogenesis in an in vitro model of the human conducting airway epithelium. Virus Research, 133(1): 33-44. DOI: http://www.doi.org/10.1016/j.virusres.2007.03.013

Singhal $T$ (2020). A review of coronavirus disease-2019 (covid-19). The Indian Journal of Pediatrics, 87(4): 281-286. DOI: http://www.doi.org/10.1007/s12098-020-03263-6

Solari S, and Baker RJ (2007). Mammal species of the world: A taxonomic and geographic reference by d. E. Wilson; d. M. Reeder. Journal of Mammalogy, 88(3): 824-830. DOI: http://www.doi.org/10.1644/06-MAMM-R-422.1

Solari S, Sotero-Caio CG, and Baker RJ (2019). Advances in the systematics of bats: Towards a consensus on species delimitation and classifications through integrative taxonomy. Journal of Mammalogy, 100(3): 838-851. DOI: http://www.doi.org/10.1093/jmammal/gyy168

St John SE, Tomar S, Stauffer SR, and Mesecar AD (2015). Targeting zoonotic viruses: Structure-based inhibition of the 3c-like protease from bat coronavirus hku4--the likely reservoir host to the human coronavirus that causes middle east respiratory syndrome (MERS). Bioorganic and Medicinal Chemistry, 23(17): 6036-6048. DOI: http://www.doi.org/10.1016/j.bmc.2015.06.039

Teeling EC, Scally M, Kao DJ, Romagnoli ML, Springer MS, and Stanhope MJ (2000). Molecular evidence regarding the origin of echolocation and flight in bats. Nature, 403(6766): 188-192. DOI: http://www.doi.org/10.1038/35003188

Tiwari R, Dhama K, Sharun K, Iqbal Yatoo M, Malik YS, Singh R, Michalak I, Sah R, Bonilla-Aldana DK, and Rodriguez-Morales AJ (2020). Covid19: Animals, veterinary and zoonotic links. Veterinary Quarterly, 40(1): 169-182. DOI: http://www.doi.org/10.1080/01652176.2020.1766725

Tsagkogeorga G, Parker J, Stupka E, Cotton JA, and Rossiter SJ (2013). Phylogenomic analyses elucidate the evolutionary relationships of bats. Current Biology, 23(22): 2262-2267. DOI: http://www.doi.org/10.1016/j.cub.2013.09.014

Tsang KW, Ho PL, Ooi GC, Yee WK, Wang T, Chan-Yeung M, Lam WK, Seto WH, Yam LY, Cheung TM et al. (2003). A cluster of cases of severe acute respiratory syndrome in hong kong. The New England Journal of Medicine, 348(20): 1977-1985. DOI: http://www.doi.org/10.1056/NEJMoa030666

Vaqué Rafart J (2005). Síndrome respiratorio agudo grave (sars). Anales de Pediatría, 62: 6-11.

Varia M, Wilson S, Sarwal S, McGeer A, Gournis E, Galanis E, Henry B, and Hospital Outbreak Investigation Team (2003). Investigation of a nosocomial outbreak of severe acute respiratory syndrome (sars) in Toronto, Canada. Canadian Medical Association Journal, 169(4): 285-292. Available at: https://pubmed.ncbi.nlm.nih.gov/12925421/

Wang LF, Shi Z, Zhang S, Field H, Daszak P, and Eaton BT (2006). Review of bats and sars. Emerging Infectious Diseases, 12(12): 1834-1840. DOI: http://www.doi.org/10.3201/eid1212.060401

Wong ACP, Li X, Lau SKP, and Woo PCY (2019). Global epidemiology of bat coronaviruses. Viruses, 11(2): Article number 174. DOI: http://www.doi.org/10.3390/v11020174

World Health Organization (WHO) (2020a). Coronavirus disease (covid-19) pandemic. Available at: https://www.who.int/emergencies/diseases/novelcoronavirus-2019

World Health Organization (WHO) (2020b). Coronavirus disease (covid-19) weekly epidemiological update and weekly operational update. Available at: https://www.who.int/emergencies/diseases/novel-coronavirus-2019/situation-reports/

World Health Organization (WHO) (2020c). Middle east respiratory syndrome coronavirus (mers-cov) - Saudi Arabia. Available at: https://www.who.int/csr/don/02-jul-2020-mers-saudi-arabia/en/

Wrapp D, Wang N, Corbett KS, Goldsmith JA, Hsieh CL, Abiona O, Graham BS, and McLellan JS (2020). Cryo-em structure of the 2019-ncov spike in the prefusion conformation. Science, 367(6483): 1260-1263. DOI: http://www.doi.org/10.1126/science.abb2507

Xiao K, Zhai J, Feng Y, Zhou N, Zhang X, Zou JJ, Li N, Guo Y, Li X, Shen X et al. (2020). Isolation of SARS-CoV-2-related coronavirus from Malayan pangolins. Nature, 583(7815): 286-289. DOI: http://www.doi.org/10.1038/s41586-020-2313-X

Yang YL, Qin P, Wang B, Liu Y, Xu GH, Peng L, Zhou J, Zhu SJ, and Huang YW (2019). Broad cross-species infection of cultured cells by bat hku2related swine acute diarrhea syndrome coronavirus and identification of its replication in murine dendritic cells in vivo highlight its potential for diverse interspecies transmission. Journal of Virology, 93(24): 01448-01419. DOI: http://www.doi.org/10.1128/JVI.01448-19

Yu WB, Tang GD, Zhang L, and Corlett RT (2020). Decoding the evolution and transmissions of the novel pneumonia coronavirus (SARS-CoV-2 / hcov-19) using whole genomic data. Zoological Research, 41(3): 247-257. DOI: http://www.doi.org/10.24272/j.issn.2095-8137.2020.022

Zaki AM, van Boheemen S, Bestebroer TM, Osterhaus ADME, and Fouchier RAM (2012). Isolation of a novel coronavirus from a man with pneumonia in Saudi Arabia. New England Journal of Medicine, 367(19): 1814-1820. DOI: http://www.doi.org/10.1056/NEJMoa1211721

Zhang J, Guo L, Xu Y, Yang L, Shi H, Feng L, and Wang Y (2017). Characterization of porcine epidemic diarrhea virus infectivity in human embryonic kidney cells. Archives of Virology, 162(8): 2415-2419. DOI: http://www.doi.org/10.1007/s00705-017-3369-2

Zhang T, Wu Q, and Zhang Z (2020). Probable pangolin origin of SARS-CoV-2 associated with the covid-19 outbreak. Current Biology, 30(7): 13461351, e1342. DOI: http://www.doi.org/10.1016/j.cub.2020.03.022

Zhang YZ, and Holmes EC (2020). A genomic perspective on the origin and emergence of SARS-CoV-2. Cell, 181(2): 223-227. DOI: http://www.doi.org/10.1016/j.cell.2020.03.035

Zhou L, Li QN, Su JN, Chen GH, Wu ZX, Luo Y, Wu RT, Sun Y, Lan T, and Ma JY (2019). The re-emerging of sads-cov infection in pig herds in southern China. Transboundary and Emerging Diseases, 66(5): 2180-2183. DOI: http://www.doi.org/10.1111/tbed.13270

Zhou P, Fan H, Lan T, Yang XL, Shi WF, Zhang W, Zhu Y, Zhang YW, Xie QM, Mani S et al. (2018). Fatal swine acute diarrhea syndrome caused by an hku2-related coronavirus of bat origin. Nature, 556(7700): 255-258. DOI: http://www.doi.org/10.1038/s41586-018-0010-9

Zou L, Ruan F, Huang M, Liang L, Huang H, Hong Z, Yu J, Kang M, Song Y, Xia J et al. (2020). SARS-CoV-2 viral load in upper respiratory specimens of infected patients. New England Journal of Medicine, 382(12): 1177-1179. DOI: http://www.doi.org/10.1056/NEJMc2001737

To cite this paper: Bonilla-Aldana DK, Toro-Ortiz C, Jimenez-Salazar P, Guevara-Manso V, Jimenez-Diaz SD, Bonilla-Aldana JL, Gutierrez-Grajales EJ, Pecho-Silva S, Paniz-Mondolfi A, Suárez JA, Pachar MR, Martinez-Pulgarin DF, Zambrano LI, Soler-Tovar D, Rodriguez-Morales AJ, and Mattar S (2021). The Broad Range of Coronaviruses Co-existing in Chiropteran: Implications for One Health. World Vet. J., 11 (2): 170-180. 